DOI: https://doi.org/10.47405/mjssh.v6i12.1196

\begin{tabular}{|c|c|}
\hline 4 & Malaysian Journal of Social Sciences and Humanities (MJSSH) \\
\hline 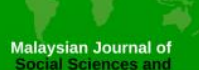 & Volume 6, Issue 12, December 2021 \\
\hline (MJ-sSH) & e-ISSN : 2504-8562 \\
\hline & $\begin{array}{l}\text { Journal home page: } \\
\text { www.msocialsciences.com }\end{array}$ \\
\hline
\end{tabular}

\title{
Public Interest Disclosure in Labuan Offshore Banking: Is Statutory Intervention Necessary?
}

\author{
Nur Hazirah Zainudin'1, Norhashimah Mohd Yasin'1, Zulkifli Hasan² \\ 1Department of Civil Law, Ahmad Ibrahim Kulliyyah of Laws, \\ International Islamic University of Malaysia (IIUM), Malaysia \\ 2Office of Deputy Rector of Student Development and Community Engagement, \\ International Islamic University of Malaysia (IIUM), Malaysia
}

Correspondence: Nur Hazirah Zainudin (nurhaziraa@gmail.com )

\begin{abstract}
Such inquiry like the recent Pandora Papers requires further legislative measure in offshore banking. While banking secrecy is legitimate privacy and viable, it has different character to tax evasion and money laundering activities. This article attempts to analyse public interest disclosure, onshore and offshore banking secrecy law from the perspective of statutory and judicial approaches. Statutory and judicial approaches show that banking secrecy is regarded as strict liability offense in onshore banking. The question arises whether public interest disclosure should be allowed as statutory intervention in Labuan offshore in response to a case like Pandora Papers? This research employs doctrinal analysis to unearth and address a necessary legislative measure for further development in descriptive and prescriptive manner. From the findings, it is evident that statutory intervention is deemed required to assist public interest disclosure for further inquiry and the general rule banking secrecy stated in Section 178 of the Labuan Financial and Securities Services Act 2010 (ACT 704) and Section 139 of the Labuan Islamic Financial and Securities Services Act 2010 (ACT 704). In this case, extensive provisions should be addressed in Section 178 of the Labuan Financial and Securities Services Act 2010 and Section 139 of the Labuan Islamic Financial and Securities Services Act 2010 regarding public interest disclosure within Malaysian offshore context that is fundamentally distinctive from the onshore banking. The forthcoming legislative measure is necessary to prevent such further sail in offshore banking.
\end{abstract}

Keywords: banking secrecy, public interest disclosure, Labuan Financial and Securities Services Act 2010, Labuan Islamic Financial and Securities Services Act 2010, offshore banking, Pandora Papers

\section{Introduction}

Pandora papers hit many news headlines (Journalism, 2021). It is the world's unprecedent disclosure on offshore financial scandal involving many countries after Panama Papers, Luxembourg Leaks, Paradise Papers and many more. The Guardian, in describing Pandora Papers exposed by International Consortium of Investigative Journalism stated that "a leak of 11.9 millions files from 14 different offshore services providers around the world that revealed how the global elite use tax havens to legally avoid paying billions in taxes, and how they are increasingly taking advantage of the Unites States' liberal trust laws" (Roche, 2021). That is to say, Pandora Papers revealed major claim of tax evasion and money laundering activities escape in offshore involving the world elites, politicians, 
public officials and public figures that are subject to further inquiries (Journalism, 2021). Malaysia is not exceptional under the centre of attention after the disclosure (Aidila Razak, 2021). In the case of Pandora Papers, the general rule of law remains that no person shall be guilty unless he is proven guilty. Therefore, such claims require further legislative measure to analyse its legitimacy and loophole when conducting further inquiries and investigation on the part of government, legislature, offshore authority and whistleblower promptly.

From the legal perspective of offshore banking, offshore banking is relatively different from the onshore. Offshore banking is defined as the following:

"cities, areas, or countries which have made a conscious effort to attract...no resident foreign currency-denominated business...by adopting a flexible attitude where taxes....and regulations are concerned." The term 'offshore' is further specified as 'either investment located purposely in specific foreign jurisdiction...the legislative and tax frameworks and regulatory authorities of which are less restrictive in comparison with their home-base...specifically designated facilities or financial 'free' zones, available to ....[investors] which are exempted from all or specific regulatory controls/ taxes on international...activities that otherwise apply in the rest of the local economy." (Antone, 2014, p. 8)

Pandora Papers has justified further legislative measure is required to uncover the claimed tax evasion and money laundering activities hidden in vulnerable offshore financial industry for further inquiry. Without negating banking secrecy legitimacy and purpose, this article attempts to provide further perspective that offshore banking secrecy must be proportionate with changing financial environment and challenge to serve justice. Banking secrecy is viable, nevertheless it can be abused (Mohd Yasin \& Zul Kepli, 2018). Many countries like the ones in the Europe (Rankin, 2021) and the US (Roche, 2021) have begun to call for a more tighter offshore banking law by wittering banking secrecy, as of date whilst the counterpart countries are concerned about the sovereignty in this issue. Besides the existence of Anti-Money Laundering, Anti-Terrorism Financing and Proceeds of Unlawful Activities Act 2001 (AMLATFPUAA 2001) and tax evasion regimes that impose a strict due diligence in banking activities and tax chasing, this article presents that both laws need further support from Public Interest Disclosure Act due to the limitation.

After the disclosure of Pandora Papers, offshore banking secrecy receives many countries' appeal to be revisited (Roche, 2021). It can be implied that offshore banking secrecy is a continuous emerging area of law due to a huge series of offshore financial scandal in question. Generally, banking secrecy is qualified but not absolute as decided in an English case of Tournier v National Provisional Bank. ${ }^{1}$ In deciding whether disclosure of client account by the bank was a breach of banking secrecy to prove that an employee is a heavily abettor, the court further described four exceptions under the general rule of banking secrecy. In Tournier's case, the four exceptions as the following:
"At the present day I think it may be asserted with confidence that the duty [of secrecy] is a legal one arising out of contract, and that the duty is not absolute but qualified. It is not possible to frame any exhaustive definition of the duty. The most that can be done is to classify the qualification and to indicate its limits ... On principle I think that the qualifications can be classified under four heads: (a) where disclosure is under compulsion by law; (b) where there is a duty to the public to disclose; (c) where the interests of the bank require disclosure; (d) where the disclosure is made by the express or implied consent of the customer."

In this case, the court held that, the bank was allowed to disclose in the justification of public interest as an exception to general rule of banking secrecy. Hence, such disclosure was not amounted to breach of banking secrecy. This case leads to the codification and application of banking secrecy in the onshore banking in many Commonwealth countries. Ten years later, banking secrecy was imposed as

\footnotetext{
${ }^{1}$ Tournier v National Provisional Bank [1924] 1 KB 461.
} 
criminal and civil sanction upon the breaches of banking secrecy law by Switzerland in 1934 . Switzerland embarked banking secrecy as political and financial refuge to protect foreign accounts and assets of discriminated groups of people who fled to Switzerland from being prosecuted and assets confiscated by Nazi government during World War II and French Revolution (Mohd Yasin \& Zul Kepli, 2018)(Antone, 2014). Switzerland is not declared as offshore. However, banking secrecy, business advantages and low tax evasion are pari materia with the offshore banking.

Offshore banking receives attention from the United States and other European countries to witter banking secrecy for tax evasion. With the recent disclosure of Pandora Papers, political attention is getting higher. Nevertheless, the application of banking secrecy exception is preserved in the offshore banking perspective. Anti-money laundering and tax avoidance legal mechanism, are among the accepted legislative controls in the offshore perspective. However, banking secrecy is subject to other regulatory mechanism. Banking secrecy is contentious notwithstanding its legitimate privacy and commercial for banking industry player and foreign investor in offshore banking. While the exception is disputed, there are support and opponent to wittering banking secrecy in the offshore banking. Developing countries, for example, use banking secrecy as essential political economic mechanism. It has privacy and commercial value to attract foreign investors. Furthermore, foreign investors perceive these offshores advantages and geographical location as cost effective for their businesses. The opponent to wittering banking secrecy concerns about territorial sovereignty and comity issue. United States, for example, has been constant in putting guide to other countries in the pursuit to identify tax evasion of United States of America citizens through the Foreign Account Tax Compliance Act. Foreign Account Tax Compliance Act signatories are bound to report to the United States Internal Revenue Service regarding all United States of America citizen accounts, including onshore and offshore financial institutions in Malaysia.

The recent Pandora Papers draw the need to balance between two contrasting perspectives. Having four exceptions, banking secrecy exception of public interest is the most relative to further analyse to curtail banking secrecy. Regardless of the contention of ambiguity, broad and subjectivity presented to disregard its legitimacy, public interest disclosure was established in English Law since 1857. Initially, it is mostly recognised as a defence and equity in the breach of statutory duty of confidentiality. The recent development that witnesses public interest stands a legislation in assisting whistleblowing in making public interest disclosure excluding confidentiality. There are United Kingdom Public Interest Disclosure 1998, Public Interest Disclosure Act 1994 (ACT), Whistleblowers Protection Act 1994 (Queensland), Whistleblowers Protection Act 1993 (South Australia), Public Interest Disclosures Act 2002 (Tasmania), and Public Interest Disclosure Act 2003 (Western Australia) and the latest Australia Treasury Law Amendment (Enhanced Whistleblower Protection) Act 2019, specifically designed to assist public interest disclosure in financial sector.

In 1990, The Jack Committee suggested that banking secrecy should be supported by statutory legislation as a clear intervention to ensure certainty and consistency in judicial interpretation (Berhe, 2008). By looking at the current phenomena in offshore banking, this suggestion can be considered in the future perspective of offshore banking after experiencing a series of disclosure such as Panama Papers, Luxembourg Leaks and Paradise Papers. The recent Pandora Papers post substantial dilemma to weigh the scale of two perspectives of banking secrecy as discussed above. Nevertheless, this article presents that public interest disclosure can be measured as abovementioned laws. This article findings show that further development is needed from the statutory and judicial perspective of banking secrecy in onshore and offshore in Malaysia.

\section{Research Method}

This study employed qualitative research. It is a purely doctrinal approach. The study also examined relevant legislation relating to public interest disclosure in banking sector in Malaysia, namely the including Section 6 of the Whistleblower Protection Act 2010 (WPA 2010), Section 133 of the Financial Services Act 2013 (FSA 2013) and Section 145 of Financial Services Act 2013 (IFSA 2013), Section 178 of the Labuan Financial Services and Securities Act 2010 (LSFSA 2010) and Section 139 
of the Labuan Islamic Financial Services and Securities Act 2010 (LIFSA 2010) The Anti-Money Laundering, Anti-Terrorism Financing and Proceeds of Unlawful Activities Act (AMLATFPUAA 2001), the Australian Treasury Amendment (Enhanced Whistleblower Protection) Act 2019 and so forth. The other relevant sources such as legal textbooks, legal journal articles, and reputable websites are also referred as secondary source. Besides, this study conducted a case study method to analyse court cases involving public interest disclosure in Malaysian onshore and offshore banking sector.

\section{Secrecy in Onshore Banking Under Section 133 of Financial Services Act 2013 and Section 145 of Islamic Financial Services Act 2013}

For onshore banking, banking secrecy is addressed in Section 133 of the FSA 2013 and Section 145 of the IFSA 2013. It is originated from the leading case of Tournier v National Provisional Bank ${ }^{2}$. However, there are different approaches found on how banking secrecy exception on public interest is observed within the banking legislation of Commonwealth countries and their judicial approaches. One of the identified approaches is that there is general rule of banking secrecy. However, the exception of public interest is not statutorily stated. The absence of statutory approach leads to two preliminary findings. First, the absence opens to judicial activism and authority to further elaborate public interest according to case-to-case basis. Second, it is regarded as a strict liability offence for breaching general rule of banking secrecy. Section 97 of Financial Services Act 2013 makes it permissible in writing to the Central Bank of Malaysia. This approach is admissible. However, political detrimental requires alternative medium for public interest disclosure to be made.

While whistleblowing is recognised as one of the significant legal mechanisms nowadays, Section 6 of the Whistleblower Protection Act 2010 limits whistleblower to disclose what is not contrary to other existing law. This provision limits protection given under Section 10 of the Whistleblower Protection Act 2010 to what is allowed to be disclosed only. Given this situation, it is argued that public interest disclosure can only be made if protection is guaranteed under the Whistleblower Protection Act 2010 to the extension of public interest disclosure. Political structure in banking sector or government is a great potential in being detrimental to morally upright bankers or citizens to come forward in making public interest disclosure. Without denying the existing reporting channels, it is further argued that these official channels are limited by Section 6 of the Whistleblower Protection Act 2010 to what is allowed by the other existing laws. The reason for this development is obvious, whistleblower or public interest disclosure needs a safer and convenient medium to blow the whistle. It is further argued that blowing the whistle is not giving a wide spectrum of defamatory and lies to be convened in public space at any cost. Nonetheless, it is designated as an alternative to alert the authorities and public that such disclosure requires further inquiry when official channels are political to whistleblower. In response to Pandora Papers, Section 6 of the Whistleblower Protection Act 2010 must further extend disclosure to any public interest matter notwithstanding detriments from the other existing laws, specifically offshore banking legislative measures.

The recent disclosure in the public interest can be seen in the cases of National Fedlot Corporation $v$ Public Bank Berhad, ${ }^{3}$ Public Prosecutor v Mohd Rafizi bin Ramli \& Anors and Mohd Rafizi Ramli \& Anor v Public Prosecutor ${ }^{4}$. Based on the case of National Fedlot Corporation v Public Bank Berhad, two bankers made disclosure in the public interest. A customer's account was disclosed in assisting whistleblowing disclosure. The court did not give protection to the whistleblower. The court held that the bank was liable collaterally with the bankers' disclosure for breaching banking secrecy. In this case, protection was not given to public interest disclosure in onshore banking sector.

In the criminal case of Public Prosecutor v Mohd Rafizi bin Ramli \& Anors, the two accused bankers were charged under criminal offence of breaching banking secrecy as stated in Section 97(1) of the repealed Banking and Financial Institutions Act 1989. The charge was on the basis of having access to

\footnotetext{
2 Tournier v National Provisional Bank [1924] 1 KB 461

${ }^{3}$ National Feedlot Corporation Sdn. Bhd. \& Ors V Public Bank Berhad [2018] MLJU 766.

${ }^{4}$ Mohd Rafizi Ramli \& Anor v Public Prosecutor [2020] 12 MLJ 823.
} 
the information illegally and disclosing it to the public at a press conference attended by the huge media coverage. In defence, the defendants argued that disclosed information in the name of public interest should be protected, as a whistleblower and a responsible Member of Parliament under Whistleblower Protection Act 2010. The Session Court did not accept the defence and found them guilt for making disclosure of the questionable transactions through the bank's customers' accounts. The breach of the duty of secrecy under Section 97 of the repealed Banking and Financial Institutions Act 1989 imposed the sentence of 30 months jail under Section 103(1)(a) of the repealed Banking and Financial Institutions Act 1989.

In the case of Mohd Rafizi Ramli \& Anor v Public Prosecutor, a disclosure on a customer's bank account was made by bankers and a Member of Parliament in the public interest over several questionable transactions. Such disclosure was brought in the court for breaching banking secrecy. The bankers and Member of Parliament seek protection as a whistleblower later, as they made such disclosure in the public interest. The Session Court found them guilty for breaching banking secrecy, a strict liability offence. On appeal, admissibility of photocopied evidence was brought against the prosecution as against Section 65 of the Evidence Act 1950, which requires strict liability offence conviction upon primary evidence. The High Court accepted the argument and discharged the appellants. These cases show that public interest is not accepted as an exception to the general banking secrecy as decided in Tournier's case.

In contrast, public interest disclosure nevertheless was accepted to justify the professional privilege of a law firm to be ceased in the case of Attorney General of Hong Kong v Lorrain Esme Osman, ${ }^{5}$. In this case, the lawyer presented confidential communication with his clients to the court, who was charged with illegal transaction. Such disclosure was justified in the public interest. Having two different approaches above, statutory intervention is needed to further assist consistency and legitimacy of public interest disclosure as a further legislative measure to combat any threat against public interest in banking sector.

\section{Paradigm for Secrecy in Offshore Banking}

Labuan is located at off coast of Sabah, East Malaysia. In 1990, Labuan is declared as an international offshore. The main Labuan offshore economic business comprises of tourism, oil and gas, developing halal hub industry, fishing and financial services. It is named after Labuan International Business and Financial Centre incorporated by Labuan International Business and Financial Centre. Labuan International Business and Financial Centre is wholly owned by Labuan Financial Services Authority. In order to support Labuan offshore financial activities, the governing law for Labuan Offshore financial activities is regulated by the Labuan Financial Services Authority through the Labuan Financial Services and Securities Act 2010 and Labuan Islamic Financial Services and Securities Act 2010. That is to say, the Labuan banking sector has a different set of banking law and controlling authority from onshore the Financial Services Act 2013, the Islamic Financial Services Act 2013 and Bank Negara Malaysia. As of date, there are 61 banks registered in Labuan offshore banking (L. F. Authority, 2021). Among the 61 offshore banks are the United Overseas Bank Limited, The Bank of Nova Scotia, The Bank of East Asia Limited, RHB (L) Ltd, Kuwait Finance House (Labuan) Limited, Chatay United Bank, CIMB (L) Limited, Bank Mualamat Malaysia Berhad Labuan Branch, Bank Islam Malaysia Berhad Labuan Offshore Branch, Baxian Private and Investment Bank, Bank AlHabib Limited, Bank of America, Hong Leong Bank Berhad Labuan International Branch, Asia Investment Banking Corporation, Deutsche Bank, National Association, Taishin International Bank Co. Ltd, NATIXIS, and so forth. It is identified that the offshore banks are a range of various local and international banks.

Being separated from the legal perspective of onshore financial centre, there are several incentives offered under the Labuan Financial Services and Securities Act 2010 and Labuan Islamic Financial Services and Securities Act 2010 to run financial businesses in Labuan offshore with a low tax law

\footnotetext{
${ }^{5}$ Attorney General of Hong Kong v Lorrain Esme Osman [1994] 3 MLJ 480.
} 
regime at three percent net audited profit, tax avoidance and several business privileges. The justification of offering low tax regime is to attract foreign businesses investment in the offshore region. In sum, it is perceived as cost effective infrastructure for businesses. Further, banking secrecy has economic and political paradigm to certain extent. Labuan offshore is governed by Labuan Financial Services Authority, as a central authority, regulatory, supervisory, enforcement authority and development of the Labuan International Business and Financial Centre and services. Furthermore, Labuan Financial Services Authority is in charge of administering, enforcing and carrying out and giving effect to the provisions of the Labuan Financial Services and Securities Act 2010, Labuan Islamic Financial Services and Securities Act 2010 and all other laws relating to business and financial services in Labuan offshore financial businesses. Besides that, Labuan Financial Services Authority has to conduct the international financial transactions in accordance with the laws, maintain good reputation, carry out further research for the development, suggest recommendation for the development, collaborate with all Labuan financial industrial players and provide advice to the government with regards to financial services in Labuan offshore (Annual Report 2019, 2019, p. 12).

There are several legislative measures found with regards to prudential aspect of offshore banking corporate governance such as the existence of Labuan Financial Services Authority Anti-Corruption Committee. It is noted that Rule 14.2 of the Labuan Financial Services Authority Guidelines on Corporate Governance For Labuan Banks And Labuan (Re)Insurers highlights the requirement to establish whistleblowing policy in offshore financial institutions (L. F. S. Authority, 2019). In this regard, most of offshore banks adopt their onshore banks whistleblowing policies that rely on the Whistleblower Protection Act 2010. In reference to the limitation in Section 6 of the Whistleblower Protection Act 2010 as discussed above, offshore banks' whistleblowing policies can be affected by the limitation (Leong, 2017, p. 10).

Figure 1: Offshore Banking Corporate Governance

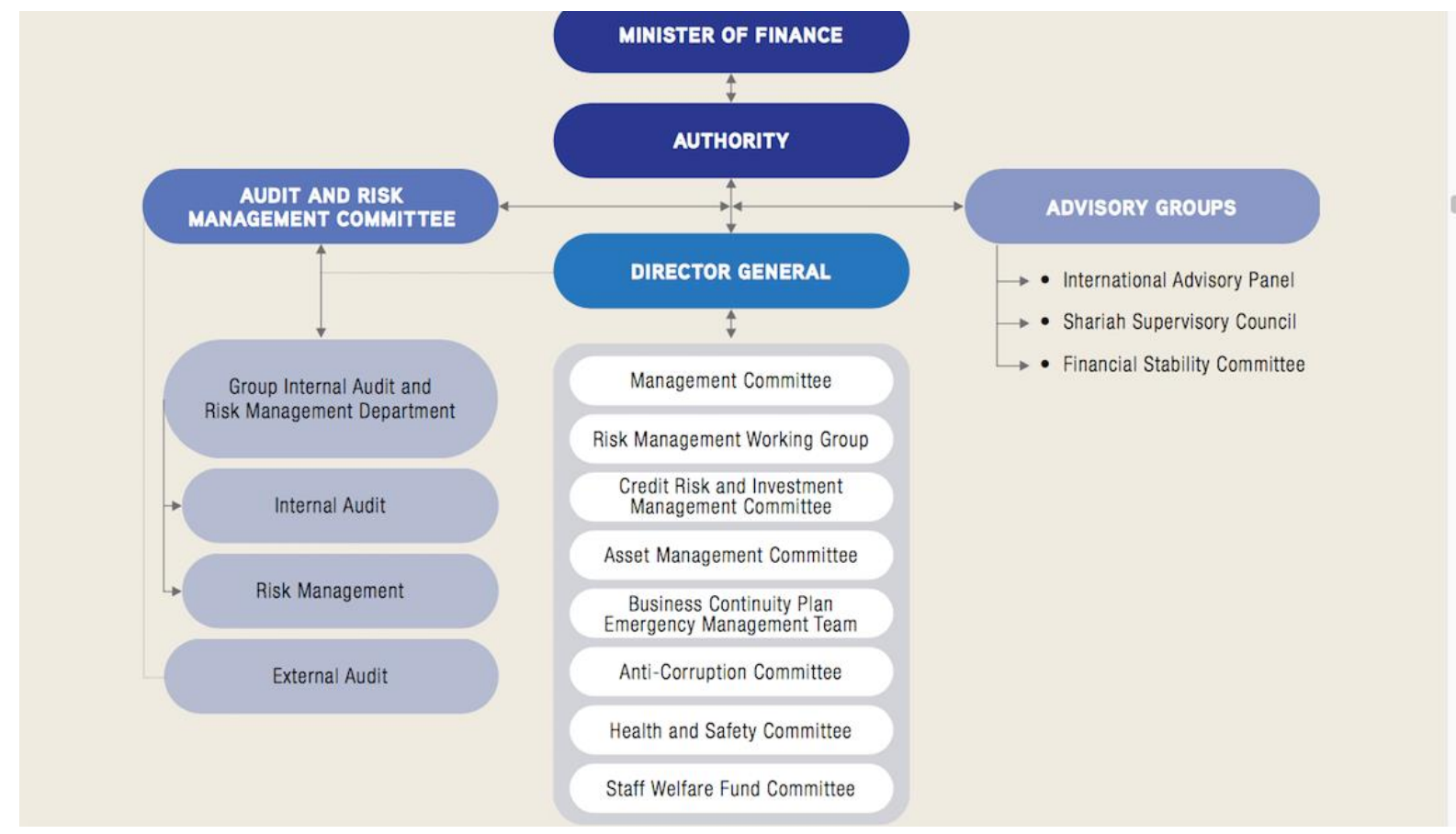

Source: Annual Report 2019 (2019)

According to Labuan Offshore annual report in 2019, the Labuan FSA Anti-Corruption Committee are the authority in charge to set law and regulatory policy, standard of procedure, strengthening governance and integrity, detection, compliance, punishment and asset recovery aspect. Meanwhile, whistleblowing policy mentions and guarantees about protection of confidentiality and adversarial actions against whistleblower only (Annual Report 2019, 2019, p. 12). According to Section 178 of the Labuan Financial Services and Securities Act 2010 and Section 139 of the Labuan Islamic Financial 
Services and Securities Act 2010, extension of scope of disclosure is not mentioned to further highlight that offshore banking secrecy allows public interest disclosure to curtail banking secrecy. Based on this statutory analysis, it is found that both onshore and offshore banking secrecy are pari materia. Both laws do not state public interest as one of the exceptions protected for such disclosure being made. This situation puts judicial interpretation to further position public interest disclosure in offshore banking. There is no specific law addressing whistleblower protection in making public interest disclosure. Therefore, it can be inferred that offshore banking relies on the Whistleblower Protection Act 2010 as a whistleblower law in offshore banking. Having analysed the judicial approaches towards public interest disclosure in onshore banking secrecy, it can be argued that offshore banking legislation also requires further legislative measure in conferring protection to whistleblower who comes forward in making disclosure in the public interest.

Labuan offshore banking businesses are also subject to the Anti-Money Laundering, Anti-Terrorism Financing and Proceeds of Unlawful Activities Act 2001. 'Know your customer' under customer due diligence is the strictest stage of assessment in opening an offshore banking account. There are other guidelines to further assist the Anti-Money Laundering, Anti-Terrorism Financing and Proceeds of Unlawful Activities Act 2001 such as:

i. Guidelines on Anti-Money Laundering and Counter Financing of Terrorism (AML/CFT) Banking Sector

ii. Guidelines on Electronic 'Know-Your-Customer' (e-KYC) for Digital Financial Services

iii. Guidelines on Politically Exposed Person - Family Members and Close Associates of Politically Exposed Person.

iv. Directive on Implementation of Targeted Financial Sanctions Relating to Proliferation Financing Under The Strategic Trade Act 2010, Strategic Trade (United Nations Security Council Resolutions) Regulations 2010 and Strategic Trade (Restricted End-Users And Prohibited End-Users) Order 2010

v. The Financial Action Task Force Latest Update on High Risk and Non-Cooperative Jurisdiction

These are lists of guidelines to further assist the Anti-Money Laundering, Anti-Terrorism Financing and Proceeds of Unlawful Activities Act 2001 in identifying Suspicious Transaction Report and Cash Transaction Report from highly risk and non-cooperative countries, people like politicians and family members and targeted financial proliferation. Nonetheless, continuous financial scandals in question, a part of the recent Pandora Papers, justify further legislative measure is deemed necessary to support further inquiry on prudential aspect of offshore banking operation in the future. This is to ensure every aspect of Suspicious Transaction Report, Cash Transaction Report and public interest threats can blow the whistle. All morally upright citizens and bankers are collectively responsible to come forward in reporting and guard public interest in offshore banking. In cross reference to Section 5 of Anti-Money Laundering, Anti-Terrorism Financing and Proceeds of Unlawful Activities Act 2001 and Section 24 of Anti-Money Laundering, Anti-Terrorism Financing and Proceeds of Unlawful Activities Act 2001, the limitation puts under these provisions confine any wrongdoing report within Suspicious Transaction Report and Cash Transaction Report only. This further explains bankers are subject to banking secrecy duty and confined within Suspicious Transaction Report and Cash Transaction Report described under Section 24 of the Anti-Money Laundering, Anti-Terrorism Financing and Proceeds of Unlawful Activities Act 2001. Such disclosure under Section 24 of the Anti-Money Laundering, AntiTerrorism Financing and Proceeds of Unlawful Activities Act 2001 is guaranteed protection from criminal and civil proceedings. Notwithstanding, any permitted disclosure shall be made under authorisation of bank and request in writing to Bank Negara Malaysia as required by Section 134 (1)(b) of the Financial Services Act 2013 and Section 145 (1)(b) of the Islamic Financial Services Act 2013. Having said so, this further illustrates that first, disclosure is permitted to what is allowed by both Section 133 of the Financial Services Act 2013, Schedule 11 and Section 24 of the Anti-Money Laundering, Anti-Terrorism Financing and Proceeds of Unlawful Activities Act 2001 only. Second, permitted disclosure can be made only through the channels as prescribed by Section 2 of the Whistleblower Protection Act 2010 who describes responsible authority for banking sector such as The Central Bank of Malaysia's Federal Investigation Department and bank internal reporting 
channels, besides The Malaysian Royal Police and Anti-Corruption Commission being the main official channels. Having disregarded the development to statutory intervention like Public Interest Disclosure in banking sector, offshore banking sector is one step behind in putting commitment to combat such tax evasion and money laundering activities that have been causing unequal distribution of wealth across the globe. This situation justifies Pandora Papers' need such statutory intervention in overcoming such cases to occur within the existing offshore banking.

\section{Public Interest Disclosure in Offshore Banking}

In analysing the applicability of public interest disclosure, this article has analysed from the history of perspective of offshore banking traced in Switzerland and the very concept of banking secrecy lays as decided in Tournier's case adopted by Commonwealth countries. The facts that offshore banking is fundamentally distinctive due to political and economic privileges remain appreciated. By exploring any possible way for public interest disclosure to be accepted within offshore banking perspective, it is found that it is possible to be implemented if statutory intervention comes in place as a form of recognition and guide towards its feasibility. Without denying judicial activism approach in interpreting public interest in different area of law, offshore banking requires specific attention as emerging area after series of financial scandals and the latest, Pandora Papers. From the perspective of history, public interest is established in English law since 1954 (Koomen, 1994). Nonetheless, it is found as a defence and equity only. The Australian Treasury Amendment (Enhanced Whistleblower Protection) Act 2019 is a proof it can be done within offshore banking. For example, the Australian Treasury Amendment (Enhanced Whistleblower Protection) Act 2019 opens disclosure in the public interest within onshore banking sector. Section 1317AAA(5) of the Australian Treasury Amendment (Enhanced Whistleblower Protection) Act 2019 provides protected disclosures to include any disclosure such as the following:

"offences against, or a contravention of, a provision of the Corporations Act, the Australian Securities and Investment Commission Act, the Banking Act, the Data Collection Act, the Insurance Act, the Life Insurance Act, the National Consumer Credit Protection Act, or the Superannuation Industry (Supervision) Act, or regulations made under those laws; and/or an offence against any other law of the Commonwealth that is punishable by imprisonment for a period of 12 months or more; and/or most importantly to the present discussion to represent a danger to the public or the financial system and/or is prescribed by regulations."

It is the first stand-alone legislation in the world, as of date, that allows such disclosure to be made. There are other attempts made by other legislative measures. For example, Australian Reform Commission provides a non-exhaustive list for any new act in Australia to include public interest such as the following matters:

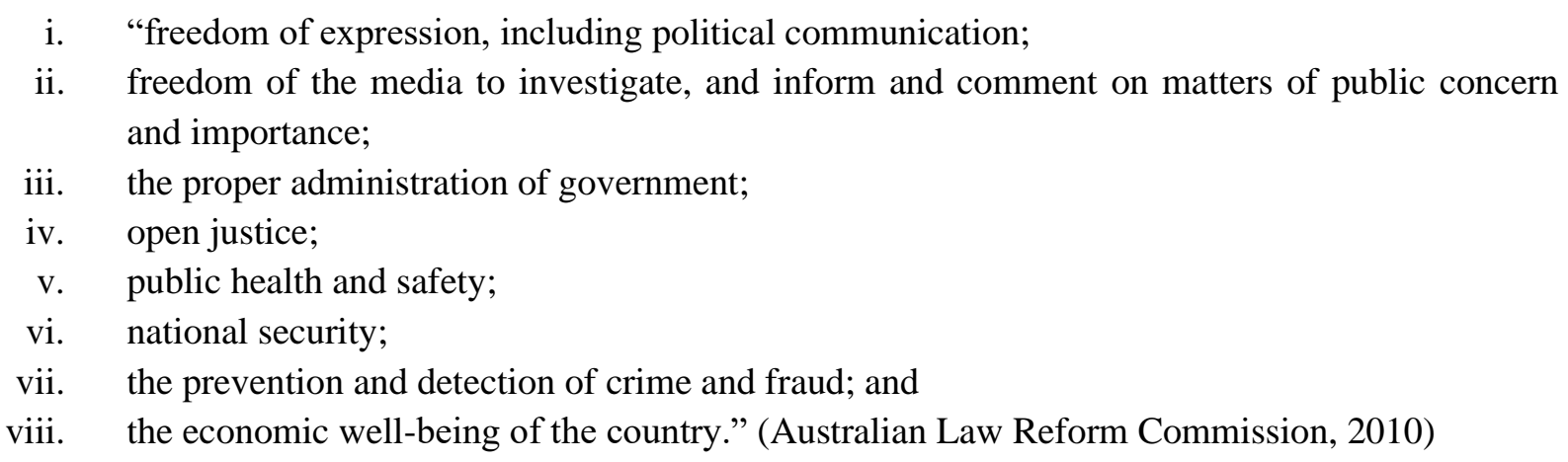

Many covenants and legislation make further attempt in recognising public interest in many other laws. For example, Article 8 of the European Convention on Human Rights (ECHR) states that: 
"...except such as is in accordance with the law and is necessary in a democratic society in the interests of national security, public safety or the economic wellbeing of the country, for the prevention of disorder or crime, for the protection of health or morals, or for the protection of the rights and freedoms of others."

The United Kingdom Public Interest Disclosure Act 1998 can be an example how statutory intervention can further assist judicial activism in recognising public interest disclosure. In the case of Chesterton Global Ltd v Nurmohamed, ${ }^{6}$ a disclosure in the public interest was protected by the court. Hence, the dismissal of an employee was regarded as reprisal against protected public interest disclosure. The company argued that the employee was in the breach of employment contract for disclosing confidential company information. The contract of employee term, however, was disregarded to allow the recognition of public interest disclosure. In this case, the court clearly made a recognition towards public interest disclosure to exclude from confidentiality duty states in the contract of employment. This case shows that a general principle of law, shall not be rigid but flexible towards what is best for the public interest bases on case-to-case basis. It is practically sociologist approach in law.

The other most significant acceptance of public interest disclosure or whistleblowing can be seen in Article 33 of the United Nation Convention against Corruption. Article 33 of the United Nation Convention against Corruption states about protection to the people who report corruption related offences from retaliation. Article 12 of the United Nation Convention against Corruption mentions that commitment in domestic laws regarding protection and disclosure should also be encompassing to the private sector. Hence, offshore banking sector should consider to further equip legal mechanism with protection to public interest disclosure. Section 8, Section 9 and Section 10 of the Whistleblower Protection Act 2010 provides a list of protection such as the protection of confidential information, immunity from civil and criminal action and detrimental action against whistleblower. Nevertheless, such protection and immunity can be revoked if a disclosure is in contrast with the other existing law. In this case, other existing law is referred to Section 134 (1)(b) of the Financial Services Act 2013 and Section 145 (1)(b) of the Islamic Financial Services Act 2013. Having said so, this further illustrates that first, disclosure is permitted to what is allowed by both Section 133 of the Financial Services Act 2013, Schedule 11 and Section 24 of the Anti-Money Laundering, Anti-Terrorism Financing and Proceeds of Unlawful Activities Act 2001 only. All these legislations do not state public interest disclosure as statutory. Therefore, any disclosure in the public interest will not warrant protection under Section 8, Section 9 and Section 10 of the Whistleblower Protection Act 2010. The judicial approach shows the courts do not regarded public interest as protected and as an exception to the general rule of banking secrecy.

\section{Implications Sovereignty and Comity in Offshore Banking Secrecy}

In addressing the need to witter absolute banking secrecy to give further opportunity for public interest legitimacy, the issue of sovereignty and comity comes into picture. This statutory intervention leads to further issue when foreign countries, in the pursuit of tax evasion and money laundering activities of their subject, seek further information from Labuan offshore banking industry. The Hague Convention on the Taking of Evidence Abroad in Civil and Commercial Matters allows states signatories to seek further exchange information between countries who ratify the convention. It is a notable number on the absence of the Southern Asian countries as signatories in this Convention. The Preamble of The Hague Convention on the Taking of Evidence Abroad in Civil and Commercial Matters states as the following:

"States signatory to the present Convention, desiring to facilitate the transmission and execution of Letters of Request and to further the accommodation of the different methods which they use for this purpose, desiring to improve mutual

\footnotetext{
${ }^{6}$ Chesterton Global Ltd. v Nurmohamed (Public Concern at Work intervening) [2017] EWCA CIV 9.
} 
judicial co-operation in civil or commercial matters, have resolved to conclude a Convention to this effect and have agreed upon the following provisions."

In Mutual Assistance in Criminal Matters Act 2002, it is argued that 'the inability of countries to work together is often exploited by criminals for money laundering and terrorism financing purpose' (Mohd Yasin \& Zul Kepli, 2018, p. 55). Further concern and critique to witter absolute banking secrecy is due to fishing expedition by the great power, as an intervention on other countries law and sovereignty (Antone, 2014). Nevertheless, it can be mitigated by having treaty and memorandums of understanding signed by signatories states. In regards to this issue, Labuan Offshore has almost general legal mechanism in addressing tax evasion and money laundering activities. Nonetheless, both offshore and onshore do not have public interest disclosure as statutory intervention in support to the existing banking legal mechanism. Judicial interpretation, neither, does not help in making public interest as a consistent legitimate for whistleblower to make such disclosure protected in onshore and offshore banking sector. Having analysed these approaches, it can be further seen as an alternative to offshore banking as compared to a special designated legislation in offshore banking.

\section{Recommendations}

Having identified the way forward, wittering absolute banking secrecy in offshore banking by providing alternative public interest disclosure as statutory intervention is deemed necessary. Public interest disclosure should stand as a statutory provision, not as defence or equity. It can be in form of subsidiary to the existing Labuan Financial Services and Securities Act 2010 and Labuan Islamic Financial Services and Securities Act 2010. Alternatively, it can be a specific banking legislation in offshore like the Australian Treasury Amendment (Enhanced Whistleblower Protection) Act 2019. The least public interest disclosure can appear, is through regulation or guidelines in treaty and memorandum of understanding between offshore territorial and states. Judicial activism can be consistent when statutory intervention is in place as further assistance, rather than being considered as defence, exception or equity. Second, it is imperative to suggest the forthcoming Malaysia Freedom of Information Act in the future to further assist any public interest disclosure being made by whistleblower and protect whistleblower in banking sector by having essential provision to highlight to the extension of public interest disclosure against any confidential law including banking secrecy. Third, bilateral of multilateral agreement between offshore territorial enforcement agencies can further strengthen the protection to public interest disclosure. In preserving sovereignty, some actions can be preserved to accommodate with offshore territorial situations. The fourth, public interest centre can further support public interest disclosure before further inquiry can be made on the report. For example, non-government organisation can provide apolitical assistance in offshore banking sector like National Oversight Whistleblower Centre further support in the onshore banking. All protection as stated in Section 10 of the Whistleblower Protection Act 2010 shall be made available and noncompromise for public interest disclosure.

\section{Conclusion}

Public interest disclosure is a significant legal mechanism nowadays. It is not absolute freedom to such lies and defamatory. However, a collective responsible to disclose questionable offshore transactions that are subject to further inquiries and investigations. No person shall be guilty unless he is proven shall be the parameter when such disclosure is made to the public. Tax evasion and money laundering activities as claimed in Panama Papers, Luxembourg Leaks, Paradise Papers and Pandora Papers, continue to occur and all these disclosures require further investigation and inquiry. While inquiring and investigating, public interest disclosure is needed to collect great evidence and information. Therefore, it is time for public interest disclosure to be made as a statutory intervention and support to counter further tax evasion and money laundering activities and other threat to public interest in offshore banking. It can be in the form of subsidiary to the existing Labuan Financial Services and Securities Act 2010 and Labuan Islamic Financial Services and Securities Act 2010, regulations or a special law. Having regarded as different in nature due to political and economic paradigm to many 
countries especially developing countries, offshore banking secrecy can be preserved by having a special treaty or memorandum of understandings between states and offshore territories in allowing public interest disclosure as alternative. Therefore, such disclosure can be protected and preserved at the same time. Public interest shares common value in many parts of the world, including offshore banking. Hence, the forthcoming legislative measure and statutory intervention in offshore banking is deemed necessary to further prevent them. Offshore banking secrecy is political and economical to many countries. In this regard, drawing a balancing legal mechanism is necessary to make banking secrecy proportionate and relevant to cater many threats against the vulnerability of offshore banking in the future.

\section{References}

Aidila Razak, A. H. (2021, October 4). Menteri, ahli politik dan hartawan Malaysia didedah jadi pemilik syarikat pesisir. MalaysiaKini. https://m.malaysiakini.com/news/593931

Annual Report 2019. (2019). https://www.labuanfsa.gov.my/clients/asset_120A5FB8-61B6-45E893F0-3F79F86455C8/contentms/img/documents/general_info/publications/Annual Reports/2019/AR_ENG(FINAL)_24092021.pdf

Antone, R.-M. B. (2014). Confidentiality in Offshore Financial Law. Oxford University Press.

Australian Law Reform Commission. (2010). Specific statutory secrecy provisions. https://www.alrc.gov.au/publication/secrecy-laws-and-open-government-in-australia-alrcreport-112/3-overview-of-current-secrecy-laws/specific-statutory-secrecy-provisions/

Authority, L. F. (2021). List of Labuan Banks and Investment Banks. Labuan Financial Services Authority. https://www.labuanfsa.gov.my/areas-of-business/financial-services/banking/list-oflabuan-banks-and-investment-banks

Authority, L. F. S. (2019). Guidelines on Corporate Governance for Labuan Banks and Labuan (Re)Insurers (Revised 2018). https://www.labuanibfc.com/clients/Labuan_IBFC_78C2FF81703A-4CAA-8926-A348A3C91057/contentms/img/Downloads/guideline/general/Guidelines on Corporate Governance for Labuan Banks and Labuan (Re)Insurers.pdf?1534391110

Berhe, T. H. (2008). Conflict between Anti-Money Laundering and Anti-Terrorism Finance Laws Requirements and Bank Secrecy and Confidentiality Laws (Issue June) [Ph.D. thesis]. University of London.

Journalism, I. C. of I. (2021). Offshore havens and hidden riches of world leaders and billionaires exposed in unprecedented leak. Journalism, International Consortium of Investigative. https://www.icij.org/investigations/pandora-papers/global-investigation-tax-havens-offshore/

Koomen, K. (1994). Breach of Confidence and the Public Interest Defence: Is It in the Public Interest? A Review of the English Public Interest Defence and the Options for Australia. Queensland University of Technology Law Journal, 10, 56-88.

Leong, C. (2017, February). A Critical Look into The Whistleblower Protection Act 2010. Policy Ideas, 36.

Mohd Yasin, N., \& Zul Kepli, M. Y. (2018). Anti-Money Laundering and Counter Financing of Terrorism Law in Malaysia. LexisNexis.

Rankin, J. (2021, October 8). European parliament calls for tougher rules on offshore wealth. The Guardian. https://www.theguardian.com/world/2021/oct/07/european-parliament-approvestougher-rules-on-offshore-wealth

Roche, D. (2021, October 8). US proposes crackdown on financial 'enablers' in wake of Pandora papers. The Guardian. https://www.icij.org/investigations/ 